\title{
O clássico em Clarice Lispector: o mito como elemento estruturante em Uma aprendizagem ou o livro dos prazeres
}

\author{
The Classic in Clarice Lispector: the myth as a structuring \\ component in the novel 'Uma Aprendizagem ou o livro dos
}

prazeres'

\begin{abstract}
Alcione Lucena de Albertim*
Resumo: A proposta do presente artigo é analisar a presença de narrativas pertencentes à tradição mítica greco-latina dentro do enredo do romance Uma aprendizagem ou o livro dos prazeres, de Clarice Lispector, identificando-as como componente da fabulação, da construção narrativa, elemento estruturante dentro da história. Para isso, fez-se o levantamento dos mitos presentes na trama, recorrendo-se às obras clássicas tais como Metamorfoses, de Ovídio, Ilíada e Odisseia, de Homero, e Teogonia, de Hesíodo, a fim de correlacionar os mitos à narrativa do romance e de analisar a sua implicação na tessitura da história.

Abstract: The present article aims to analyse the presence of narratives which belong to greek-latin mythic tradition in the romance Uma aprendizagem ou o livro dos prazeres, de Clarice Lispector, identifying it as component of the plot, of narrative construction, structural element inside the story. In this sense, a search for the existent myths in the fiction was fulfilled, making use of classical works such as Metamorphoses, by Ovid, Iliad and Odyssey, by Homer, and Theogony, by Hesiod, in order to verify the correspondence of the myths with the narrative and to analyse its implication in the story's weaving.
\end{abstract}

\author{
Palavras-chave: \\ Mitos. \\ Literatura. \\ Poiesis. \\ Narrativa.
}

\section{Keywords:}

Myths.

Literature.

Poiesis. Narrative.

\footnotetext{
* Professora do Departamento de Letras Clássicas e Vernáculas e do Programa de Pós-Graduação em Letras da Universidade Federal da Paraíba (UFPB). Coordenadora do Mythos (Núcleo de Estudos da Mitologia Greco-Latina). Doutora em Letras pela UFPB.
} 
Porque no impossivel é que está a realidade.

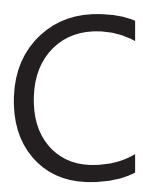

ostumamos dizer que para adentrar o domínio dos clássicos greco-latinos, é preciso ser iniciado, o que significa adentrar esse mundo em que o mito é elemento fulcral, a fim de compreender, paulatinamente, em um processo de maturação, a ética, os valores, as práticas religiosas, os papéis e os sentidos desse universo múltiplo denominado Antiguidade Clássica. Assim, compreender o mito, sobretudo o seu caráter funcional, como peça fundamental desse mundo dinâmico e arquetípico é imprescindível, para que, partindo-se do rito de iniciação, possa-se passar a fazer parte desse contexto, com o olhar voltado para o ontem e para o hoje, algo que Clarice Lispector, no âmbito da ficção, faz primorosamente através da voz ficcional do narrador, cujo foco narrativo é de terceira pessoa, em sua obra Uma aprendizagem ou o livro dos prazeres.

O mito, em seu caráter funcional, transcende o limite do tempo histórico e cronológico, uma vez que serve como instrumento de elaboração para o homem, no processo de compreensão do mundo que o circunda e no qual está inserido. Trata-se de narrativas criadas, em princípio, para explicar a origem daquilo que existe, a saber, o céu, a terra, os homens, os deuses, os animais, o amor, o ódio, a morte, a vida, os acontecimentos, as emoções que assolam o homem etc., logo, o seu subsídio é o material humano. Assim sendo, é possível abordar o mito através de vieses diversos, seja da cultura, da religião, da Antropologia, da Arqueologia, da História, da Psicanálise ou da Literatura, uma vez que o ser humano está no cerne do campo de estudo desses vários âmbitos do conhecimento.

Ainda sobre o mito, recorra-se ao teórico Cassirer, que vincula a sua origem à mesma da linguagem. Assim, o estudioso afirma:

[...] a linguagem e o mito se acham originalmente em correlação indissolúvel, da qual só aos poucos cada um se vai desprendendo como membro independente. Ambos são ramos diversos do mesmo impulso de informação simbólica, que brota de um mesmo ato fundamental e da elaboração espiritual, da concentração e elevação da simples percepção sensorial. Nos fonemas da linguagem, assim como nas primitivas configurações míticas, consuma-se o mesmo processo interior; ambos constituem a resolução de uma tensão interna, a representação de moções e comoções anímicas em determinadas formações e conformações objetivas (CASSIRER, 2013, p. 106).

Seguindo essa linha de raciocínio, percebe-se que mito e linguagem estão indissociavelmente ligados pela sua origem comum, surgiram como formas de exprimir o material psíquico através de um processo de elaboração. O meio de expressar esse material elaborado são a nomeação das coisas, a linguagem, e o processo de narração, o 
mito. Assim, mito e linguagem continuam tendo como função expressar, pela elaboração simbólica, a psique humana.

Wellek e Warren (1970, p. 191), por sua vez, esclarecem:

Historically, myth follows and is correlative to ritual; it is 'the spoken part of ritual; the story which the ritual enacts'. The ritual is performed for a society by its priestly representative in order to avert or procure; it is an 'agendum' which is recurrently, permanently necessary, like harvests and human fertility, like the initiation of the young into their society's culture and a proper provision for the future of the dead. But, in a wider sense, myth comes to mean any anonymously composed story telling of origins and destinies: the explanations a society offers its young of why the world is and why we do as we do, its pedagogic images of the nature and destiny of man.

Os autores trazem a acepção de mito que se vincula ao rito, mostrando a feição sagrada dessas narrativas, herança cultural de um povo. Por outro lado, os mitos, em um sentido mais amplo, dizem respeito, também, a histórias compostas a fim de explicar origens e destinos, porquês e éticas, transportando um sentido pedagógico. No que tange à teoria literária, os mitos aparecem como imagem ou pintura, expressão do social, do irracional, como histórias, arquétipos e elementos do universal, também como representações simbólicas, eventos no tempo dos ideais atemporais, assim como o místico. Respeitante ao seu uso na arte literária, eles comentam: "In terms of our scheme, it is a part of the syntactical, or stylistic, stratum. It must be studied, finally, not in isolation from the other strata but as an element in the totality, the integrity, of the literary work" (WELLEK; WARREN, 1970, p. 211).

Quanto à presença dos mitos na construção narrativa, percebe-se que eles the servem de subsídio, em harmonia com o restante dos elementos da fabulação. É preciso pensá-los articulados à estrutura do fazer poético, da poiesis de cada obra, que tem como instrumento a linguagem escrita e imagética e, como escopo principal, os conflitos humanos, respeitante à angústia, à alegria, ao desejo, às expectativas, à plenitude e ao vazio existencial, ao sofrimento, ao amor, àquilo que retrata a subjetividade humana. Nesse âmbito, encontra-se o mito. Desse modo, o foco do presente trabalho é buscar olhá-lo como componente da fabulação, da construção narrativa, servindo, portanto, como elemento para a mimesis e a poiesis.

Os mitos são estruturantes dentro do enredo de Uma aprendizagem ou o livro dos prazeres, de Clarice Lispector, cuja história diz respeito ao processo de aprendizagem de Loreley, personagem principal da trama, quanto à vida, configurando-se como um verdadeiro rito de passagem. Nesse processo, a princípio, a presença de Ulisses, com quem faz par, é fundamental, no entanto, à medida que ela avança em sua aprendizagem, 
vai adquirindo certa autonomia até que, na etapa final desse ciclo, ela consegue ir sozinha. Lóri, como é chamada antes de começar essa trajetória, sente-se "na condição de manca, em descompasso com o mundo" (LISPECTOR, 1998, p. 20) para, ao final, saber que possui a própria vida, e também a de Ulisses, uma vez que, apesar de haverem aprendido acerca da vida de maneira singular, o final da trajetória leva à união dos dois. Assim diz Lóri: "- Você tinha me dito que, quando me perguntassem meu nome eu não dissesse Lóri, mas "Eu". Pois só agora eu me chamo "Eu". E digo: eu está apaixonada pelo teu eu. Então nós é. Ulisses, nós é original (LISPECTOR, 1998, p. 151). E mais adiante afirma: "Aprendo contigo, mas você pensa que eu aprendi com tuas lições, pois não foi, aprendi o que você nem sonhava em me ensinar" (LISPECTOR, 1998, p. 157).

O ápice dessa aprendizagem se dá no encontro dos dois na cama, quando se amam, de corpo e de alma. E é na simplicidade que Lóri encontra o prazer, o prazer de existir. Para ela, "ser uma mulher no escuro ao lado de um homem que dormia" (LISPECTOR, 1998, p. 152), era o que almejava, pois "ela não queria nada senão aquilo mesmo que the acontecia" (LISPECTOR, 1998, p. 153).

O prazer, como dor de ser, permeia a aprendizagem de Lóri, entretanto, metamorfoseia-se na medida em que ela prossegue. Sua aprendizagem consiste em humanizar-se, processo que ocorre em etapas sucessivas de um rito, em que permeiam elementos míticos, a começar pela própria estrutura da narrativa.

É interessante observar que o tempo na narrativa se apresenta como um ciclo. Seguindo as estações da natureza, ela abre com o verão, passando pelo outono e pelo inverno, findando-se na primavera, o que é muito representativo, considerando-se, sobretudo, dois aspectos. Primeiramente, o estado de ser da personagem, cuja constituição se dá a partir de três perspectivas, a animal, em que o desejo é a força propulsora, a humana, que tem na compreensão racional a sua base, e a divina, pautada pela transcendência, as três podendo ser apreendidas separadamente em suas caracterizações, mas ao mesmo tempo entrelaçadas, pois uma atua sobre a outra. Tal estado se aproxima da própria configuração da natureza, que abarca os três âmbitos, a força bruta, instintual (perspectiva animal), o racional (perspectiva humana) e a transcendência (perspectiva divina, a partir do olhar do homem). Em segundo lugar, temos o aspecto mítico, ligado ao anterior, pois tal disposição do tempo da narrativa remete-nos ao mito do rapto de Prosérpina por Plutão, correspondentes a Perséfone e Hades na tradição grega, narrado na obra Metamorfoses, do poeta Ovídio (Ovídio, Metamorphoses, V, 341- 408).

Narra o mito que Prosérpina era filha de Ceres, deusa dos cereais, correspondente à deusa grega Deméter. Um dia, Vênus, deusa do amor e da sedução, conclama seu filho, Cupido, a usar suas armas contra Plutão, deus dos infernos, haja vista que o submundo 
era o único âmbito em que ainda não imperava o seu poder. O deus momentaneamente deixara o seu palácio a fim de se certificar de que lugar algum ameaçava ruir, uma vez que Tifeu, preso em grilhões por Júpiter, de vez em quando tentava escapar do peso dos montes que sobre ele jaziam, abalando desse modo as terras. Encontrava-se nessa condição, pois fora castigado ao tentar destronar Júpiter, ocupando os céus. Foi, nesse instante, que Cupido atingiu-o com sua flecha mais afiada, fazendo-o apaixonar-se perdidamente por Prosérpina, a quem avistara tomando banho no rio. Rapta-a, então, levando-a para o seu palácio. Ceres, ao perceber a ausência da filha, começa a procurála e termina por descobrir o que aconteceu. Tomada de furor, recusa-se a fazer a terra brotar, o que compromete a vida de todos. Júpiter, então, interfere, dizendo-lhe que a filha será devolvida, mas apenas se não houver provado do fruto, a romã, que a prenderia definitivamente ao mundo subterrâneo. Assim aconteceu, pois, com fome, provara do fruto, condenando-se a ficar junto de seu agora marido, Plutão. Como forma de trazer novamente o equilíbrio à natureza, Júpiter determina que Prosérpina passe metade do ano com o marido, no submundo, e metade com sua mãe, sobre a terra. Nesse mesmo movimento a natureza começa a funcionar. Quando está próxima a chegada da filha, Ceres se alegra, e a natureza começa a florescer, surgindo a primavera. Em seguida, vem o verão, quando Prosérpina está do lado da mãe, e a terra encontra-se madura, pronta para a colheita sob o calor do sol. Logo que vai se aproximando o momento de a deusa voltar para junto de Plutão, como reflexo da consternação de Ceres, a terra começa a se entristecer, as flores a murchar, e as folhas a secar nas árvores. É o outono chegando, a quem sucederá o inverno, quando a natureza, aparentemente morta, reflete a tristeza de Ceres, por haver perdido a filha novamente.

O mito explica o surgimento das estações do ano, que regulam a produção da terra, a sua fertilidade, a fim de que o homem possa sobreviver. Em um movimento cíclico, denota o tempo mítico, não cronológico, cujo início sempre retorna, a fim de configurar um novo ciclo, um novo começo. Na Natureza, há a força criadora, pulsional de Eros, que impele o florescimento e a procriação, força bruta, que age sobre todos os seres viventes. Nela, está inserido o homem, cuja racionalidade tenta entendê-la, domá-la e moldá-la, mas que, na realidade, não consegue abarcá-la, nem a aprender em sua totalidade, como elemento uno, e por isso mesmo ele, o homem, recorre à transcendência, à sacralidade, ao aspecto divino da natureza a fim de tentar compreender a sua abrangência.

Dessa maneira, podemos perceber Lóri, cujo processo de aprendizagem evolui nas três esferas. No animal, ela compara o seu mundo íntimo a um cavalo selvagem, que, se deixado solto, pode levá-la Deus sabe onde. Esse cavalo não será domado, mas contido, na medida em que ela atravessa o processo de humanização. E, na esfera divina, há a sua 
ligação com o Deus, a quem busca pedir, através de sua prece, e que, a princípio, não compreende, pois era olhado pelo prisma humano. O Deus está além:

Lóri passara da religião de sua infância para uma não religião e agora passara algo mais amplo: chegara ao ponto de acreditar num Deus tão vasto que ele era o mundo com suas galáxias: isso ela vira no dia anterior ao entrar no mar deserto sozinha. E por causa da vastidão impessoal era um Deus para o qual não se podia implorar: podiase era agregar-se a ele e ser grande também (LISPECTOR, 1998, p. 82).

É possível observar, portanto, que, assim como no mito narrado, em que a natureza vai se moldando a cada estação, mostrando um ciclo que do verão à primavera denota uma trajetória desde um estado de maturidade, com a conseguinte morte paulatina e a renovação com o ressurgimento da natureza como etapas inexoráveis, Lóri, em seu rito de passagem, também sofre esse processo, mas em sentido contrário. A narrativa começa no verão e, Lóri, neste momento, em sua condição infantil, busca elaborar pelo imaginário a torrente aluvião de lágrimas suscitada pela dor de ser:

[...] veio afinal o grande choro seco, choro mudo sem som algum até que para ela mesma, aquele que ela não havia adivinhado, aquele que não quisera jamais e não previra - sacudida como a árvore forte que é mais profundamente abalada que a árvore frágil - afinal rebenta dos canos e veias, então...sentou-se para descansar e em breve fazia de conta que ela era uma mulher azul porque o crepúsculo mais tarde talvez fosse azul, faz de conta que fiava com fios de ouro as sensações, faz de conta que a infância era hoje e prateada de brinquedos, faz de conta que uma veia não se abrira e faz de conta que dela não estava em silêncio alvíssimo escorrendo sangue escarlate [...]" (LISPECTOR, 1998, p. 14).

Tendo sido iniciada, Lóri experiencia mais dois momentos significativos para a sua aprendizagem de existir, ocorridos ainda no verão, a saber, o encontro na piscina com Ulisses, e o banho de mar.

Uma semana depois da última vez que vira Ulisses, ele lhe telefonou, dizendo que estava na piscina do clube, chamando-a para que ela viesse ao seu encontro. Assim, Lóri o fez, apesar de não ser na piscina que ela queria vê-lo, mas o medo de perdê-lo, fez com que ela aceitasse, embora o receio de se verem quase nus. Pela primeira vez, Lóri sentirá a felicidade, a partir da experiência da homogeneidade.

Lóri estava suavemente espantada. Então isso era a felicidade. De início se sentiu vazia. Depois seus olhos ficaram úmidos: era felicidade, mas como sou mortal, como o amor pelo mundo me transcende. $\mathrm{O}$ amor pela vida mortal a assassinava docemente, aos poucos (LISPECTOR, 1998, p. 73).

Estava ela sentada à beira da piscina, ao lado de Ulisses, com os pés dentro d'água, quando, a um movimento seu de jogar os cabelos para trás, percebe que ele a olhava 
e a desejava. Sentiu, então, um pudor de quem também deseja. Ao perceber o próprio desejo claramente, ficou arisca e dura, ficando ambos em silêncio o resto da tarde. Lóri olha para Ulisses e, em uma percepção da unicidade de tudo que existe, distingue tanto a homogeneidade quanto os liames que separam as coisas, os objetos.

Depois Lóri percebeu que esse fulgor eram os reflexos do sol antes de definitivamente morrer. Olhou para as mesinhas com para-sol dispostas em torno da piscina: pareciam sobrepairar na homogeneidade do cosmo. Tudo era infinito, nada tinha começo nem fim: assim era a eternidade cósmica. Daí a um instante a visão da realidade se desfazia, fora apenas um átimo de segundo, a homogeneidade desaparecia e os olhos se perdiam numa multiplicidade de tonalidades ainda surpreendentes: à visão aguda e instantânea seguira-se algo mais reconhecível na Terra (LISPECTOR, 1998, p. 69).

Passado esse momento, a despeito ainda da dor de continuar existindo, Lóri havia dado o primeiro passo assustador para alguma coisa. Descobrira o sublime no trivial, o invisível sob o tangível. Iniciara um caminho sem volta, irreversível. Era noite e Lóri estava triste. Ela estava só. Mas, o humano era só e era esse o caminho que percorria: o da humanização. Nesse sentido, após a tristeza sem dor que sentia, provavelmente viria alguma alegria. Adormeceu sem sentir e sonhou com Ulisses nos braços de outra mulher. Sentiu ciúme. "Também isto ela iria sofrer?" Pergunta-se. "Sim, também o ciúme, também a cólera, também tudo" (LISPECTOR, 1998, p. 76). Lóri já não é mais aquela que quer cortar a dor de sentir e assim ficar sem nada, perdida no seu próprio mundo e no alheio, sem forma de contato. Assim, impelida por esse sentimento, ela busca uma nova experiência. Ela vai à praia e, no encontro dessas duas forças, desses dois mundos incognoscíveis, o mar - a mais inteligível das inteligências não humanas - e a mulher - o mais inteligível dos seres vivos - ocorre a grande transformação. Lóri é fertilizada pela água do mar ao banhar-se nela e também bebê-la. A partir disso, ela passa a conhecer as etapas desse rito, tão antigo como a humanidade, o rito de fertilização.

É perceptível a relação desse episódio com o mito do nascimento de Afrodite, narrado na Teogonia, de Hesíodo, o que suscita um olhar mais significativo sobre ele dentro da trama (Hesíodo, Theogonia, 188-206).

$\mathrm{Na}$ tradição hesiódica, Afrodite é filha do pênis. Nascida das espumas surgidas do sêmen que cai no mar após a mutilação dos órgãos genitais de Urano (o Céu), ela provém do mar. Unida a Urano pelo coito, Gaia (a Terra) gera muitos filhos: seis Titãs, seis Titânides, três Ciclopes e três Hecatonquiros. Entretanto, Urano, que se mantinha, permanentemente, sobre Gaia, não permitia que os filhos viessem à luz, ficando eles atulhados em seu ventre. Um dia, já cansada de gerar e não poder trazer os filhos à vida, Gaia trama contra Urano. Propõe aos filhos que, forjando ela uma foice em seu ventre, 
possa um deles livrá-la do peso do pai. Cronos, o mais novo dos Titãs, aceita fazê-lo. Fica atento à espera do momento em que Urano viria ao coito com Gaia. Chega então a noite e, assim, acontece. No instante em que o pai penetra a mãe, Cronos agarra-lhe o órgão genital e o decepa, jogando-o em seguida ao mar. A dor é tão grande, que Urano (o Céu) se desprende de Gaia (a Terra), permanecendo assim até hoje. Quanto ao pênis jogado no mar, este, ejaculando ainda, lança o sêmen na água e, essa mistura, provoca as espumas de onde surgirá Afrodite. Assim narra o poeta:

\author{
O Pênis, tão logo cortando-o com o aço \\ atirou do continente no undoso mar, \\ aí muito boiou na planície, ao redor branca \\ espuma da imortal carne ejaculava-se, dela \\ uma jovem criou-se. Primeiro Citera divina \\ atingiu, depois foi à circunfluída Chipre \\ e saiu veneranda bela deusa, ao redor relva \\ crescia sob esbeltos pés. A ela. Afrodite \\ deusa nascida de espuma e bem-coroada Citeréia \\ apelidam homens e deuses, porque da espuma \\ criou-se e Citeréia porque tocou Citera, \\ Cípria porque nasceu na undosa Chipre, \\ e Amor-do-pênis porque saiu do pênis à luz. \\ Eros acompanhou-a, Desejo seguiu-a belo, \\ tão logo nasceu e foi para a grei dos deuses \\ (Hes., Theog., 188-202). ${ }^{1}$
}

Afrodite representa a fecundidade. Uma vez saída do mar, fertilizado pelo sêmen de Urano, ela traz em si todos os elementos da vida. Com o seu nascimento, Eros passa a agir através dela, tanto como força criadora, quanto como força sexual. A natureza se abre, brota sob a influência da deusa e, em ciclos de criação e de destruição, se renova sob a sua força.

Essa mesma força de criação e destruição passa a impelir Lóri em sua trajetória, quando primeiramente tocada pela humanização. Ela, para quem a humanidade era como morte eterna que, no entanto, não tivesse o alívio de enfim morrer (LISPECTOR, 1998, p. 23), é iniciada na vida, adentrando esse ciclo de vida e de morte, uma vez que compõe a dinâmica de ser humano:

Então o que chamava de morte a atraía tanto que só poderia chamar de valoroso o modo como, por solidariedade e pena dos outros, ainda estava presa ao que chamava de vida. Seria profundamente amoral não esperar pela morte como os outros esperam por essa hora final. Teria sido esperteza dela avançar no tempo, e imperdoável ser mais sabida que os outros. Por isso, apesar da curiosidade intensa que tinha pela morte, Lóri esperava (LISPECTOR, 1998, p. 35).

\footnotetext{
1 Tradução de J. A. A. Torrano.
} 
É, a partir do seu encontro com o mar, que ela passa a viver essa dinâmica, de morte e de vida, reiterada ao longo da narrativa.

Lóri vai à praia, bem cedo, não havia ninguém, apenas um cão negro. Era ela e o mar. Em etapas sucessivas de um rito, ela o adentra. Primeiramente olha para ele, ela hesita porque vai entrar. É seu exíguo e delimitado corpo que penetra na vastidão do mar. "Esse corpo entrará no limitado frio que sem raiva ruge no silêncio da madrugada" (LISPECTOR, 1998, p. 79). E, assim, acontece. Em um momento arquetípico, como sendo o primeiro a acontecer, e por isso mesmo vir a ser modelo, ela é fecundada pela vida: "Com a praia vazia nessa hora, ela não tem o exemplo de outros humanos que transformam a entrada no mar em simples jogo leviano de viver" (LISPECTOR, 1998, p. 79).

Ela vai entrando na água gélida, que lhe arrepia em ritual as pernas. Ela é tomada de alegria, uma alegria que não sorri e que é séria. $E$, nesse instante, inicia-se uma relação com o cheiro da maresia, que será reiterada ao longo da narrativa, remetendo-a a sua possível ancestralidade, uma vez que o seu nome, Loreley, é de uma personagem lendária do folclore alemão, cantada em um poema do autor alemão Heine, fato referido por Ulisses a Lóri. Ele lhe conta que, segundo a história, Loreley seduzia os pescadores com o seu canto e eles, embevecidos, terminavam morrendo. Tal referência alude ao episódio do canto das sereias, $^{2}$ na Odisseia, de Homero, canto XII, em que Odisseu e seus companheiros, após saírem da ilha de Circe, se deparam com a ilha das Sereias, seres monstruosos, cujo canto melodioso enfeitiçava aqueles que o ouviam (Homero, Odyssea, XII, 165-200).

Assim, adverte-os Circe:

\begin{abstract}
Às Sereias chegarás em primeiro lugar, que todos os homens enfeitiçam, que delas se aproximaram. Quem delas se acercar, insciente, e a voz ouvir das Sereias, ao lado desse homem nunca a mulher e os filhos estarão para se regozijarem com o seu regresso; mas as Sereias o enfeitiçam com o seu límpido canto, sentadas num prado, e à sua volta estão amontoadas ossadas de homens decompostos e suas peles marcescentes (Hom., Od., XII, 39-46). ${ }^{3}$
\end{abstract}

O ponto de convergência entre o nome da personagem e o episódio da Odisseia diz respeito a dois quesitos. Primeiro, o canto sedutor, seja das sereias, seja de Lóri, que pode ser fatal; segundo, a referência ao mar que, no texto homérico, é aludido tanto

\footnotetext{
${ }^{2}$ No texto homérico, não fica claro se as Sereias são seres metade mulher, metade pássaro ou metade mulher, metade peixe. Depois de Homero, as referências mais antigas que existem a essas personagens são duas, o vaso coríntio, de aproximadamente 560 a.C., que, segundo Timothy Gantz (2004), encontra-se em Boston, e o texto de Apolônio de Rhodes, Argonáuticas, Canto IV, versos 891-921. Nas duas referências, as Sereias são mostradas como seres metade mulher, metade pássaro.

${ }^{3}$ Tradução de Frederico Lourenço.
} 
por Odisseu estar em sua nau com os companheiros, quanto pelo fato de as sereias viverem em uma ilha rodeada pelo mar. Em relação à personagem do romance, o mar, mais especificamente o seu cheiro, simboliza uma das etapas de aprendizagem de Lóri, concernente, sobretudo, ao despertar para a vida através das sensações sinestésicas. Por outro lado, o canto sedutor de Lóri, assim como o das Sereias, seria fatal para Ulisses caso ele sucumbisse, pois seria apenas mais um dentre os amantes que ela tivera e que serviram, unicamente, para Ihe saciar o desejo erótico. Ulisses, no entanto, queria-a por inteiro, para além da satisfação sexual.

Assim, Lóri é tomada pelo cheiro. "O cheiro é de uma maresia tonteante que a desperta de seu mais adormecido sono secular" (LISPECTOR, 1998, p. 70). Mais à frente, completa: "O caminho lento aumenta sua coragem secreta - e de repente ela se deixa cobrir pela primeira onda! O sal, o iodo, tudo líquido deixam-na por uns instantes cega, toda escorrendo - espantada de pé, fertilizada" (LISPECTOR, 1998, p. 79).

Iniciada, ritualisticamente, ela mergulha, repetindo o movimento de imersão, é fertilizada novamente. Com as mãos em forma de concha, ela a enche com água salgada e bebe-a em goles grandes. "E era isso o que estava lhe faltando: o mar por dentro como o líquido espesso de um homem" (LISPECTOR, 1998, p. 80). Mergulha novamente, novamente bebe da água, sem sofreguidão, pois já conhece o rito. "Ela é a amante que não teme, pois sabe que terá tudo de novo" (LISPECTOR, 1998, p. 80). Nesse sentido, o cheiro do mar remete ao desejo sexual de Lóri que, a partir da fertilização ocorrida ao engolir a água, representação do sêmen masculino, agora está impregnado de sentido. Permanece parada dentro d'água por um tempo e depois sai, caminhando dentro da água de volta à praia. E ela caminha dentro das águas.

A fertilização de Lóri se dá pela presença do elemento masculino na água, o que remete ao mito do nascimento de Afrodite, saída das espumas provocadas pelo esperma de Urano. Ao beber da água, Lóri é fecundada de vida e, desse modo, ela sai das águas, assim como Afrodite saiu. Ela afirma, então, perguntando: "Como explicar que o mar era o seu berço materno mas que o cheiro era todo masculino? Talvez se tratasse da fusão perfeita. Além do que, de madrugada, as espumas pareciam mais brancas" (LISPECTOR, 1998, p. 112).

À força criadora de Afrodite, opõe-se a força destruidora de Ares, deus da guerra. Afrodite e Ares são amantes, e a despeito de se contraporem, suas forças se complementam, regendo o ritmo dos ciclos de renovação da natureza, na qual o homem está inserido, sendo exatamente esse ritmo o que possibilita o equilíbrio da natureza. Lóri, uma vez iniciada, passa a funcionar nesse ritmo: 
A força de destruição ainda se continha e ela não entendia por que vibrava de alegria de ser capaz de tal ira. É que estava vivendo. E não havia perigo de realmente destruir ninguém ou nada porque a piedade era nela tão forte quanto a ira: então ela queria destruir a si mesma que era a fonte daquela paixão (LISPECTOR, 1998, p. 114).

Ao se compreender nessa dinâmica pulsional, Lóri aceita, simplesmente aceita, com ternura, estar no mistério de ser viva.

la esperar comendo com delicadeza e recato e avidez controlada cada mínima migalha de tudo, queria tudo pois nada era bom demais para a sua morte que era a sua vida tão eterna que hoje mesmo ela já existia e já era (LISPECTOR, 1998, p. 119).

E chega o outono. Nele, Lóri, saída da infância, adolesce. Esperando o telefonema de Ulisses que não ocorria, ela decide ir ao coquetel da Diretoria dos Cursos Primários, no Museu de Arte Moderna, uma vez que ela era professora do primário. Retraída, não tinha o hábito de sair de casa. Saía pouco. Apesar de hesitante, decide ir à festa.

[...] pintou demais os olhos e demais a boca até que seu rosto branco de pó parecia uma máscara: ela estava pondo sobre si mesma alguém outro: esse alguém era fantasticamente desinibido, era vaidoso, tinha orgulho de si mesmo. Esse alguém era exatamente o que ela não era. (LISPECTOR, 1998, p.84)

Lóri chega ao local, um salão descomunal que, pelo tamanho, dava a impressão de haver poucas pessoas dentro do seu espaço. Ela se sente incomodada, principalmente pela máscara que usava, mas ao mesmo tempo, sabia que, sem pintura, seria a nudez da alma, e ela não estava preparada. Ao adentrar o recinto, conversa com algumas pessoas, inclusive com dois homens que haviam sido seus amantes, mas que agora não passavam de estranhos. Apesar do incômodo, não estava indiferente; estava muito emocionada, pois, há muito tempo, não via gente. Mas, não suportou mais e foi embora. Pegou um táxi, percebeu que o chofer a olhava. Possivelmente achou que ela era prostituta, pensou Lóri, pela maquiagem exagerada. Lembrou-se, então, dos teatros gregos, em que os atores usavam máscaras para representar os personagens. Para ela, dentre as qualidades de um ator, estavam as mutações sensíveis do rosto, logo, o uso da máscara as esconderia. E pensa: "Por que então Ihe agradava tanto a ideia de atores entrarem no palco sem rosto próprio?" (LISPECTOR, 1998, p. 86).

No teatro antigo, a máscara figurava como acessório, de modo a trazer à cena, juntamente com as vestimentas, elementos da expressividade trágica, em se tratando da tragédia, a fim de suscitar no público o efeito trágico próprio desse gênero, como 
também elementos próprios da comédia, em se tratando do gênero cômico, provocando o riso no público. Nesse sentido, Vernant e Frontisi-Ducroux (1999, p. 176) comentam:

A invenção do teatro, do gênero literário que encena o fictício como se fosse real, só podia intervir no quadro do culto de Dionísio, deus das ilusões, do tumulto e da confusão incessante entre a realidade e as aparências, a verdade e a ficção.

A assertiva do estudioso corrobora o sentido teatral da cena acima. A maquiagem usada por Lóri para ir à festa, palco nessa representação, retrata a máscara em cena. Naquela altura do seu processo de maturação, da busca da sua verdade, já não suporta mais o seu uso, pois remete às ilusões em que vivia mergulhada. Para Lóri, o uso da máscara talvez fosse um dar-se tão relevante quanto o dar-se pela dor do rosto, funcionando, portanto, como representação do sentir humano, haja vista a máscara usada na encenação da tragédia exprimir dor, e a da comédia, uma alegria exagerada.

Pensa ela:

Inclusive os adolescentes, que eram de rosto puro, à medida que iam vivendo, fabricavam a própria máscara. E com muita dor. Porque saber que de então em diante se vai passar a representar um papel que era de uma surpresa amedrontadora. Era a liberdade terrível de não ser.

Também Lóri usava a máscara de palhaço da pintura excessiva. Aquela mesma que nos partos da adolescência se escolhia para não se ficar desnudo para o resto da luta (LISPECTOR, 1998, p. 86).

Lóri não achava mal mostrar o rosto nu, mas tal exposição poderia levá-la a se ferir, o que poderia provocar a assunção de uma máscara involuntária e terrível, sendo mais seguro antes que isso acontecesse, escolher ser uma máscara, ser uma persona.

Mas dentro do táxi, a caminho de casa, talvez pelo olhar do chofer, ou mesmo por uma palavra dele, de repente, "a máscara de guerra da vida crestava-se toda como lama seca, e os pedaços irregulares caíam no chão com um ruído oco" (LISPECTOR, 1998, p. 87). Agora estava de rosto nu, e "o rosto de máscara crestada chorava em silêncio para não morrer" (LISPECTOR, 1998, p. 87).

Chegam o inverno e Lóri, desnudada da antiga máscara, começa a amadurecer. Ulisses Ihe telefona, convidando-a para almoçar na Floresta da Tijuca. Ela, então, veste seu suéter vermelho e sua saia xadrez e, ao esperar por Ulisses no portão de casa, segura a sua sombrinha vermelha, contrastando com a cor do tempo chuvoso. Tal vestimenta já Ihe prenuncia a primavera. Ao chegarem no restaurante, Ulisses e Lóri esperam em uma antessala antes de serem chamados à mesa quando o almoço estivesse pronto. Como chovia muito, não havia outros clientes. E, nessa espera, Lóri observava a chuva: 
Quando ela pensou que, além do frio, chovia como que no mundo inteiro, não pôde acreditar que tanto de bom the fosse dado. Era o acordo da Terra com aquilo que ela nunca soubera que precisava com tanta fome de alma (LISPECTOR, 1998, p. 106).

A chuva como acordo entre Céu e Terra é símbolo da fertilização, aquilo que Lóri nunca soube que precisava antes da sua própria fertilização no banho de mar. Tal referência alude, mais uma vez, ao episódio de Urano e Gaia, na narrativa hesiódica, em que ele é decepado pelo filho Cronos (Hes., Theog., v. 154-210). Como a vida é Eros agindo ininterruptamente, a pulsão da vida não pode cessar, uma vez que a própria vida, em todas as instâncias da natureza, pereceria. Assim sendo, após a mutilação, Urano continua fecundando Gaia, sempre que lança sua semente representada pela chuva.

Chega a primavera, com os seus primeiros calores, "tão antigos como um primeiro sopro" (LISPECTOR, 1998, p. 117). Primavera é a estação de Afrodite, pois é a deusa quem abre a natureza, fazendo-a florescer e procriar. Com ela, toda a vida tem começo. No âmago dessa estação está Eros, força pulsional, criadora e sexual.

Para Lóri, é o prenúncio de uma nova condição: "Muito antes de vir a nova estação já havia o prenúncio: inesperadamente uma tepidez de vento, as primeiras doçuras do ar. Impossível que essa doçura de ar não traga outras! diz o coração se quebrando" (LISPECTOR, 1998, p. 117).

De fato, outras doçuras virão promovendo uma nova condição de existir. Na primavera, Lóri atinge a maturidade, quando a natureza se faz criança. Iniciada, ela experimenta e continua a sua busca no mundo. Ela vai à feira.

Foi à feira de frutas e legumes e peixes e flores: havia de tudo naquele amontoado de barracas, cheias de gritos, de pessoas se empurrando, apalpando o material a comprar para ver se estava bom - Lóri foi ver a abundância da terra que era semanalmente trazida numa rua perto de sua casa em oferenda ao Deus e aos homens. Sua pesquisa do mundo não humano, para entrar em contato com o neutro vivo das coisas que, estas não pensando, eram no entanto vivas, ela passeava por entre as barracas e era difícil aproximar-se de alguma, tantas mulheres trafegavam com sacos e carrinhos (LISPECTOR, 1998, p. 125).

Em contato direto, através da sinestesia, com os elementos vivos da natureza, Lóri vivencia. Vivencia, através da visão, as cores vivas das frutas e legumes. "O sangue puro e roxo escorria de uma beterraba esmagada no chão" (LISPECTOR, 1998, p. 125), o que remete ao próprio fluxo menstrual. Vê as batatas em uma cesta, cujas cores nuançadas e formatos diversos prendiam seu olhar. Com as duas mãos pega uma delas. A pele era lisa, era parda e fina como a de uma criança recém-nascida. Ao manuseá-la, no entanto, sentia brotos perceptíveis apenas ao tato. Anda pelas barracas, esgueirando-se, pois havia 
muitas pessoas na feira, o que era um aprendizado para ela. Vai à barraca dos ovos, eram brancos. Na barraca dos peixes, sente novamente o cheiro da maresia, semicerra os olhos, aspirando-o. Vai à barraca das peras. Pareciam tão suculentas, que Lóri comprou uma. E de fato estava, o que comprovou depois de dar uma dentada na pera. "Apenas quem tinha comido uma pera suculenta a entenderia" (LISPECTOR, 1998, p. 126), pensou Lóri.

Como se ela fosse um pintor que acabasse de ter saído de uma fase abstracionista, agora, sem ser figurativista, entrara num realismo novo. Nesse realismo cada coisa da feira tinha uma importância em si mesma, interligada a um conjunto mas qual era o conjunto? (LISPECTOR, 1998, p. 126).

A resposta ela irá encontrar nos braços de Ulisses. Uma noite, acordada pelo prazer de dormir, ela vai à cozinha para pegar um copo de água. Foi, então, para o terraço. Chovia fortemente, e ali permanecia, olhando a chuva e se molhando toda. Pensou: "Nunca imaginara que uma vez o mundo e ela chegassem a esse ponto de trigo maduro!" (LISPECTOR, 1998, p. 145). Lóri simplesmente era, assim como a chuva. "Era uma mulher, era uma pessoa, era uma atenção, era um corpo habitado olhando a chuva grossa cair" (LISPECTOR, 1998, p. 145). Subitamente, mas sem perturbação, sentiu vontade de dar essa noite a alguém. Esse alguém só podia ser Ulisses. E do jeito que estava, de camisola e sem maquiagem, pega um casaco, algum dinheiro na bolsa, e sai para pegar um táxi para a casa de Ulisses. Chega, enfim. "Nunca um ser humano tinha estado mais perto de outro" (LISPECTOR, 1998, p. 147).

Beijaram-se demoradamente. Olham-se sem pudor, um nos olhos do outro e, ali mesmo, deitados no chão, amam-se. Mesmo já tendo tido cinco amantes, aquela era a primeira vez de Lóri.

Mulher e homem se encontram, se reconhecem, e identificados com a unicidade da natureza, assim como todas as pessoas, são deuses em potencial. Afirma Ulisses: "Não falo de deuses no sentido divino. Em primeiro lugar devemos seguir a Natureza, não esquecendo os momentos baixos, pois que a Natureza é cíclica, é ritmo, é como um coração pulsando" (LISPECTOR, 1998, p. 154).

Finda-se a aprendizagem, começará outro ciclo, assim como ocorre na natureza. Ambos, Lóri e Ulisses, aprenderam, em ritmos diferentes, em movimentos distintos. Cada um percorreu seu caminho individualmente, para, ao final da trajetória, se encontrarem. A busca de Lóri é a da humanização. Loreley, a princípio, tenta seduzir Ulisses com o seu canto de sereia impelida pelo desejo puramente carnal de possuí-lo, assim como as Sereias tentaram aprisionar Odisseu, herói da Odisseia, de Homero, Canto XII, em seu périplo de volta para casa após a destruição de Troia, único humano a ouvir o canto das 
Sereias sem sucumbir. Ele ordena à tripulação do seu navio que tapem os ouvidos com cera, de modo a não serem seduzidos, e consequentemente morram, ficando presos em seu canto, sem comer e sem beber. Quanto a ele, manda que o amarrem fortemente ao mastro do navio, e que sob nenhuma circunstância o soltem, mesmo que ele, Odisseu, ordene. Ulisses ouve o canto sedutor de Lóri, mas não sucumbe, espera por ela, por seu aprendizado. O que retém Odisseu são as cordas e a força dos companheiros que a seguram. Ulisses é impedido pelo desejo de querer vê-la aprender a viver, e desse modo, unir-se verdadeiramente a ele. E como Odisseu e Penélope, eles finalmente se encontram.

O Odisseu da Odisseia, diferentemente do Odisseu da Ilíada, busca a humanização. Na llíada, ele é o herói que luta para imortalizar o seu nome, a glória imperecível, através da excelência guerreira em campo de batalha. Na Odisseia, ele é o herói humanizado, que quer não a imortalidade, mas o retorno para o lar, ó vóotoç. A ele a ninfa Calipso oferece a imortalidade e a virilidade, vivendo a seu lado como uma divindade. Mas o que ele deseja é voltar para Penélope, sua esposa, e para o seu filho, Telêmaco. Ele quer voltar para Ítaca, seu lar, e envelhecer ao lado de Penélope. Passam-se dez anos até que Odisseu consiga chegar em casa. Ele passa por inúmeras provações, que vão Ihe fortalecendo o desejo da mortalidade, da humanidade.

Lóri, assim como Odisseu, busca humanizar-se. Ela quer tudo que a torna humana. Conciliando-se consigo mesa, no movimento natural e cíclico da natureza, ela chega à porta de um começo.

Assim, há uma inversão na história de Lóri e Ulisses em relação à da Odisseia. Ulisses é, na realidade, a Penélope de Lóri, o qual aguarda, lealmente, o seu retorno.

\section{Referências}

\section{Documentação textual}

APOLLONIO RODIO. Le Argonautiche. Traduzione di Guido Paduano. Milano: Bur Rizzoli, 2013.

HESÍODO. Teogonia, a origem dos deuses. Tradução de J. A. A. Torrano. São Paulo: Iluminuras, 2007.

HOMERO. Ilíada. Tradução de Frederico Lourenço. São Paulo: Companhia das Letras, 2013.

HOMERO. Odisseia. Tradução de Frederico Lourenço. São Paulo: Companhia das Letras, 2011.

LISPECTOR, C. Uma aprendizagem ou o livro dos prazeres. Rio de Janeiro: Rocco, 1998. 


\section{Obras de apoio}

CASSIRER, E. Linguagem e mito. São Paulo: Perspectiva, 2013.

GANTZ, T. Mythes de la Grèce archaïque. Paris: Belin, 2004.

OVÍDIO. Metamorfoses. Tradução de Paulo Farmhouse Alberto. Lisboa: Cotovia, 2007.

VERNANT, J.-P.; FRONTISI-DUCROUX, F. Figuras da máscara na Grécia Antiga. In:

VERNANT J.-P.; VIDAL-NAQUET, P. (org.). Mito e tragédia na Grécia Antiga. São Paulo: Perspectiva, 1999, p. 163-178.

WELLEK, R.; WARREN, A. Theory of Literature. London: Harcourt Brace \& Company, 1970. 